\title{
Importance of Parallel - Bareboat Charter Registration and Its Connection with Marine Insurance
}

\author{
G. Daniil \& P. Saviolakis \\ University of Piraeus, Piraeus, Greece
}

\begin{abstract}
The impact of the Parallel Registration is pretty apparent in modern shipping. Traces of Parallel Registration, Dual Registration, Demise Charter Registration and Bareboat Charter Registration can be found in both the Open Ship Registries system and the traditional Closed Ship Registries. The stance of both the new maritime nations and the traditional Flag States towards Parallel Registration are analyzed. The reasons for the acceptance of the Parallel Registration include the positive impact to the maritime companies, the benefits to the Ship Registries involved and the satisfaction of particular ambitions on behalf of the States that embrace this institution. There is further specialization in the implications of Parallel Registration in the Marine Insurance practices especially in the case of bareboat chartering. The status of the ship owner, the ship charterer and the mortgage lender are further examined under the auspices of Parallel Registration in the event of a Marine Insurance incident.
\end{abstract}

\section{INTRODUCTION}

Parallel Registration has become an inherent element of modern shipping. This is the outcome of a long lasting process and it took a long period of time for the maritime industry to adopt the practices of Parallel Registration. The term Parallel Registration itself is not exhausting and can be combined with the terms Dual Registration, Demise Charter Registration and Bareboat Charter Registration. The evolution and gradual domination of the Open Registries is the determinant factor for the wider acceptance of the practices of the Parallel Registration in the maritime sector.

There are obvious benefits that accompany the application of Parallel Registration for both the States involved and the Ship Registries themselves. Apart from the Open Ship Registries that are the driving forces behind the establishment of Parallel
Registration the traditional Closed Ships Registry have more or less adopted a positive stance towards Parallel Registration.

Apart from the evaluation of the importance of Parallel Registration the current paper examines the synergies that are created between Parallel Registration and Marine Insurance in particular. For this reason the latter part of the essay focuses on the special provisions governing the issues of Marine Insurance when a vessel is under bareboat chartering registration.

\section{THE EVOLUTION OF PARALLEL REGISTRATION}

The practice of Parallel Registration of ships is not observed exclusively in the modern shipping 
industry. We have to keep in mind that the roots of Parallel Registration can be traced back in the 18th century. During this era, Genovese shipowners chose to use the French and the British flag interchangeably, while trading in the waters of the Gulf of Corinth in Eastern Mediterranean . Furthermore, Greek subjects of the Ottoman Empire were using the Russian flag in addition to the Ottoman flag. The main reason for adopting this parallel flag was the commercially preferential status that accompanied the Russian flag following the Treaty of Kuchuk-Kainarji in 1774.

Nowadays, the modern trend of Parallel Registration commences with the German Law of the Flag Act of 1951. According to this legal arrangement, German shipowners were allowed to flag-out by registering their ships to an Open Registry, usually the Panamanian ship Registry. At the same time they bareboat chartered these ships to their German maritime company thus having the right to raise the German flag. Nevertheless, the last few decades the mechanism of Parallel Registration more often works in a different way. The owner of the vessel usually forms a maritime company in an Open Registry and bareboat charters, with the method of parallel-out (demise-out), the vessel to this company consequently raising the flag of the Open Registry.

The legal framework that defines the details of Parallel Registration is set by the International Conventions of UNCLOS I of 1958, UNCLOS III of 1982 and mainly the United Nations Convention on Conditions for Registration of Ships of 1986, which is not yet in force due to the still pending adherence of the minimum number of States that need to sign it. While in both the Article 6 of the Convention of the High Seas-UNCLOS I and the Article 92 of the UNCLOS III Flag-States are entitled to grant their nationality to commercial ships, however the case of Parallel Registration is not specifically dealt with. Additionally, many legal experts advocate the view that although dual documentation of ships is forbidden, Bareboat Registration is not affected by this restriction .

The step forward was accomplished in Article 11, Paragraphs 4 \& 5 and Article 12 of the United Nations Convention on Conditions for Registration of Ships of 1986, which reprises (Farthing and Brownrigg 1997) the conditions of UNCLOS I and UNCLOS III with the addition, though, of special arrangements for the case of Bareboat Charter and its implications to Parallel Registration (United Nations 1986). Among other provisions, the Registry of destination in order to accept the flag-in vessel has to establish a mechanism of adequate exchange of information with the Registry of origin, thus reassuring that the duration of the Parallel Registration matches with the duration of the relevant Bareboat Charter Party.

\section{CONNECTION BETWEEN PARALLEL REGISTRATION AND OPEN REGISTRIES / FLAGS OF CONVENIENCE}

Parallel Registration offers the shipowner the opportunity to operate a vessel under most favorable terms by exploiting the advantages of an Open
Registry or a Flag of Convenience, while at the same time retaining the nationality of the original Registry. The advantages of the Open Registries and the Flags of Convenience to a maritime company that chooses to register a vessel via Parallel Registration have both economic and legal nature. As far as it concerns the economic aspect of transferring a vessel to a Parallel Registry, the most common cause is the need of the maritime company to be more competitive. By this means it will have the opportunity to achieve lower tax obligations, flexibility concerning the nationality of the crew and thus lower operating costs.

Furthermore, when it comes to ship finance, the maritime company will have the option to choose the most appropriate Ship Registry that satisfies the demands of the financial institution that is going to supply the funds and in turn ask for a ship mortgage. The legal framework concerning the mortgage of ships of the Ship Registry has to be acceptable to the bank that finances the acquisition of the vessel. One should also not underestimate the fact that by exercising Parallel Registration a number of shipowners seek to hide their true identity and nationality.

The Open Registries and the Flags of Convenience are highly competitive in order to attract as much tonnage as possible from the international market. For this reason there are willing to offer the opportunity of Parallel/Bareboat Charter Registration to their potential customers who seek for a more flexible and economical business framework or simply try to achieve banking finance. The vast majority of Open Registries and Flags of Convenience, including the largest Registries of quality, have adopted a positive attitude towards Parallel, as is the case of Panama, Marshall Islands and Liberia

The rule is that the duration of the Parallel Registration is in accordance with the duration of the Bareboat Charter Party . Exemptions regarding the duration of the Parallel Registration can be found in the case of Open Registries such as Bermuda, where the initial duration of five (5) years can be renewed for additional maximum five (5) years each time. Even more flexible is the approach of Cyprus where albeit the initial duration is limited to the duration of the Bareboat Charter Party, thereafter the duration can be rearranged upon permission of the Authorities of the Ship Registry

A key factor that can potentially restrict the options concerning the Parallel Registration is the compatibility of the legal systems of both the Registry of origin and the Registry of destination. Some Open Registries such as Malta demand that both Registries' national laws permit this type of legal arrangements . The same condition can be found in Cyprus. On the other hand, some Open Registries, as is the case of Bahamas and Palau, bypass this obstacle by merely accepting a written consent by the Authorities of the other Registry. 
4 THE ATTITUDE OF THE TRADITIONAL MARITIME NATIONS TOWARDS PARALLEL REGISTRATION

Traditional maritime nations historically have responded quite differently to the challenge of flagging-out of their fleets. Some of them, as is the case of Denmark and USA, have chosen to remain Closed Ship Registries, while others, such as UK and Greece have adopted a more flexible approach by relaxing the criteria for the application of genuine link. Many of the traditional maritime countries have even moved a step forward by establishing International Registries, as in Norway (NIS), Germany (GIS) and Denmark (DIS), while others have created Off-shore Registries as is the case of Isle of Man and Bermuda regarding the UK. Hence, the approach of the traditional maritime nations is all but uniform when it comes to Parallel Registration.

The majority of traditional maritime nations, even those that operate Closed Ship Registries, have chosen to implement Parallel Registration of ships as is the case of Denmark. The same provision applies to the International Registry of Denmark (DIS) too, as it actually happens with the vast majority of the rest of the International Registries. The trend towards the gradual approval of Parallel Registration among the traditional maritime nations can be clearly investigated in the case of Australia. Initially, Bareboat Charter Registration resulted in the cancellation of the primary Registry, but over the years the Australian maritime Authorities commenced to approve of the Parallel Registration in both the Closed Registry and the Australian International Ship Registry (AISR).

Interestingly, some countries with Closed Ship Registries, such as Azerbaijan and Kazakhstan, have the precondition of obligatory Parallel Registration to their national Closed Ship Registry for foreign flagged ships that intent to navigate in their domestic waters .

A somewhat different situation is the case of the Germany. First of all, all vessels that are registered to the German International Ship Registry (GIS) need to be registered to the German Closed Ship Registry, thus applying Parallel Registration. This is a peculiarity of the German ship registration system, since International Registries generally do not require for prior registration to the relevant national Closed Registry. Additionally, vessels registered to the German Ship Registries are permitted to temporarily fly a foreign Flag by using the Parallel Registration system.

When we evaluate the more flexible Closed Registries, we can clearly distinguish between the cases of the UK Registry which accepts Parallel Registration according to the UK Merchant Shipping Act of 1995, c.21, part II and Greece where this is not possible. The Off-shore Registries, such as Bermuda, generally approve Parallel Registration since they regard it as comparative advantage in order to attract tonnage from both the Closed and Open Registries.

Only ships of approved flags are allowed to register in either the Closed Ship Registry of Denmark or the International Ship Registry (NISR) for Parallel Registration purposes. Similarly, the Isle of Man demands that the jurisdictions of both Registries are compatible.

\section{CONTRIBUTION OF PARALLEL REGISTRATION TO THE SHIPPING INDUSTRY AND THE SHIP REGISTER'S STATE}

Parallel Registration contribution to the Shipping industry spreads in various areas of concern that affect both the public and the private sector. Furthermore, it spreads to a wide range of areas of concern covering both political and financial aspect of the maritime activity.

\subsection{Contribution of Parallel Registration to the Shipping Industry}

The fact that Parallel Registration is also known as Bareboat Charter Registration is indicative of the importance of Parallel Registration to the Shipping Finance. More specifically, banking institutions that are active in the shipping sector usually provide the appropriate funds for the buying or building of ships and in turn receive the guarantee of a mortgage. For this reason it is of high importance for their legal departments to be familiar with the legal procedures that are followed by each Ship Registry. In case that the banks do not feel safe enough about the validity and the effectiveness of the mortgage, the ship might need to reflag to a more acceptable Registry. This phenomenon was apparent in many Russian-flagged vessels in the 1990's that adopted the Cypriot Flag in order to overcome the mistrust of western banks to the legal system of the Russian Registry.

When assessing the importance of Parallel Registration to the maritime companies, we cannot overlook the impact to the financial performance of the vessel, which is of utmost importance for the lending institutions. By transferring the vessel to a more cost effective Ship Registry, the maritime company gains the capability to reduce certain categories of the operating cost. These categories consist of the labour cost, expenses for social security and lower tax obligations. In this way the economic performance of the maritime company ameliorates and there is positive impact to the corporate profitability and consequently to the evaluation of the banking sector.

In many cases the ship-manager does not possess the appropriate funds for the acquisition of the vessel . In this scenario there is another private entity, the shipowner, that deals with the property issues. Everything that matters the banking finance, the mortgage and the obligations towards the Bareboat Charter Registry and the Authorities concerns the shipowner. Hence, the ship-manager can exercise his maritime skills by facing the issues that occur from the operational activity of the vessel, unaffected by the burden of the vessel as an asset.

Another outcome of significant importance that derives from the application of Parallel Registration is the flexibility of the ship-managers to choose the workforce regardless of their nationality. In 
traditional maritime nations one of the greatest disadvantages that hinder the growth or sustainability of the existing national Registries is the lack of adequate human resources to man the vessels. The scarcity of specialized seafarers can be faced by shifting via Parallel Registration to a more lax Registry concerning the nationality of the crew and the officers. There is sufficient workforce originating from third countries that can contribute to the uninterrupted evolution of the shipping industry through the channels of Registries other than the Closed Registries. It is important to keep in mind though that usually this freedom in the choice of the nationality of the crew members and the officers of the vessels come along with lower salary expenses .

Another important issues that increases the effectiveness of the vessel due to the Parallel Registration is the ability to reach a wider range of ports worldwide. The fact that there are periods of civil unrest and political turbulence in many parts of the globe poses as threat to the smooth operation of the maritime sector. A vessel might not be permitted to reach a port depending on the Flag that it flies as was the case of the South African and Israeli Flag in the past. In order to surpass this difficult situation a ship has the option to alter its nationality by registering to a suitable Ship Registry, while at the same time remaining for mortgage reasons at a different Ship Registry. It is apparent that the ownership of the vessel is different from the shipmanagement, in order to satisfy maritime traffic of certain geographic areas in troubled years.

It is true that many maritime nations offer incentives to their shipping sector in order to increase their survivability while facing foreign competition. State subsidies, guarantees, shipbuilding subsidies as well as the tonnage tax scheme are available for the maritime companies that choose to remain under the national Flag, which in most cases is more expensive to operate when compared to its competitors from abroad. In few countries, such as Germany, not only the State offers the above mentioned privileges to the ships that fly their Flag, but at the same time allows these ships through Parallel Registration to take advantage of the lower operating costs of an Open Registry. We can say that in this case maritime community members enjoy the best of two worlds.

\subsection{Contribution of Parallel Registration to the Ship Registry's State}

The positive contribution of Parallel Registration extends to the countries that have chosen to exercise it. Actually, this is the driving force behind the adoption of Parallel Registration by the majority of both the traditional maritime nations and the new maritime powers globally. One of the direct advantages of Parallel Registration is the inflow of revenues for the public budget due to the taxation of the ships that fly the Flag of the respective State. In spite of the fact that taxation through the tonnage tax scheme, that is followed by almost all of the Open, International, Off-shore Registries and a growing number of Closed Registries, in shipping is significantly lower compared to the taxation of landbased companies, there is great impact to the fiscal policy of the small countries that have exercised Parallel Registration. In fact in many cases this is main incentive for small and underdeveloped countries of the third world with no presence in the maritime matters in the past to create an Open Registry and after that to offer Parallel Registration services. In this category of countries we can distinguish among Panama , Liberia, Marshall Islands and Palau. Furthermore, it has positive impact to the foreign exchange reserves of these States, since the global currency of shipping is the US Dollar and the payment of the tax obligations of the ships are executed in this currency .

We have to keep in mind though that the more developed the State is, the less important the revenues originating from the inflow of ships are. In these cases the main objective of the State's policy is to attract maritime activity, stimulate economic growth to the country and consequently reposition itself as a maritime center. Though the influx of shipping companies, marine law firms, accounting offices, marine insurance companies, naval architect offices, ship chandlers and freight brokers many States aim to revitalize the local economy, create employment and thus maximize the benefits of the maritime industry . Examples of countries of this category are Cyprus, Malta and Singapore among others. These countries enjoy political and financial stability, have a sound base of infrastructure, solid and respectable legal systems and have created flexible Registries for the attraction of marine-related services within their borders.

It is apparent that Parallel Registration encourages the creation of a fleet that flies the national Flag. In some nations that try to overcome a difficult and destructive period in their history, Parallel Registration is a means to attract readily available tonnage and thus to build a fleet that better serves their interests. With no particular demands concerning shipping finance, local shipyards, specialized seafarers or whatsoever a State can allure ships from overseas to the national Ship Registry. Perhaps the most typical example is the maritime policy of Germany after the WWII, which albeit under most depressing financial circumstances managed to reestablish the national Registry and reconstitution the German fleet after the war. In particular, it permitted the creation of maritime companies in Germany that chartered back ships from abroad and through the Parallel Registration process they could fly the German Flag.

Apart from reconstituting the merchant fleet in troubled periods of time, traditional maritime nations have found refuge to the Parallel Registration in order to protect their maritime sector during years of normal business activity. The phenomenon of flagging-out has long threatened the very existence of traditional fleets. The growth of the Open Registries at the expense of the traditional maritime nations was a matter of concern in these countries. One of solutions that were proposed was the adoption of Parallel Registration in order to attract foreign ships in the national Registry. With this method ships that have already flagged-out could be chartered back to maritime companies established in these States and hence fly the national Flag. 
One of the main reasons that impel States to retain a minimum number of ships under their Flag is the satisfaction of their strategic needs as well as for defense purposes. Most countries depend on imports and exports for the survival of the indigenous population or the preservation of the quality of life. In this context it is of crucial importance to ensure the safe transportation of goods such food, energy resources, minerals, military supplies etc. by ships that are controlled by this State . Additionally, for States with long-distance overseas territories, such as UK and France, merchant navy is of vital importance for the confirmation of national sovereign. By preserving the existence of an adequate number of vessels flying the national Flag, the State's interests are better served. For this reason Parallel Registration was seen by many countries as method that could assist them in accomplishing their strategic ambitions.

The preservation of respectful fleet registered in the national Registry has long been seen as a tool for the exercise of political pressure and flag display by many countries . Decisions made in the context of the United Nations (UN) and more specifically the International Maritime Organization (IMO) take into consideration the volume of the tonnage that is controlled by the signing parties. Needless to say that negotiation in the place of other international or multinational organizations such as the European Union largely depends on the weight of each Member State in terms of fleet size. This is the reason that comparatively small States with considerable fleets though, such as Cyprus, Malta and Greece, play significant role in the maritime matters in European Union.

\section{ASPECTS OF MARINE INSURANCE IN PARALLEL REGISTRATION}

In an effort to achieve uniformity in international maritime transport and to address the issues arising from the bareboat, the terms of such contracts, as formulated by long-standing shipping practice, have been systematized by numerous international organizations. These charter agreements are either adopted in their full form or are taken as a basis for reaching an agreement between the parties and there are relevant additions or subtractions at the discretion of the parties.

The charterparty agreement most commonly used in international shipping practice for bareboat chartering is the one codenamed BARECON and formulated by BIMCO. BARECON was published in 1974 in the form of two types of contracts, which were incorporated into a single text in 1989 following a previous revision. Since then, BARECON has undergone other revisions, most recently in 2017, aimed at adapting to new shipping practices, facilitating contracting parties and eliminating problems encountered in implementing its previous forms.

After a brief presentation of the legal provisions and charter agreements governing the bareboat chartering and the attempt to determine its nature, key problems related to insurance will be identified and may arise during the Parallel Registration of a ship, the use of which has been granted by bareboat charter. These problems stem from the fact that during the bareboat chartering the issue of application of legal rules of more legal orders may be raised. In particular, while for the transfer of ownership and encumbrances on the ship such as mortgages, the law of the main registration is generally applied, for issues that may arise during the operation of the ship by the charterer, the law of the state of the Parallel Registry may apply.

More specifically, a key problem is identified in particular when the shipowner, who enters into a bareboat contract with the charterer, has entered into a loan agreement and the lender has entered into a mortgage on the ship to ensure that his claims are met. The risk that may arise from the existence of a condition such as the above becomes apparent if the owner has entered into a loan agreement and the lender has entered into a mortgage on the ship in order to ensure that his claims are met. In such a case, even if there is a Parallel Registration of the ship after the conclusion of a bareboat charter contract, for the mortgage and any tangible burden placed on the ship applicable will be the law governing the establishment of the mortgage, which in most cases it is synonymous with the law of the main registration. Therefore, if the shipowner grants his use to the charterer under a bareboat charter agreement, the lender may not be able to exercise his rights on board provided by the pre-registration on the ship, as the use, exploitation and control of the ship has been transferred to the charterer who now functions as its de facto owner. This is even more apparent if the charter is combined with the Parallel Registration of the vessel and its consequent inclusion in the legal status in force in the State whose flag it bears during the period of validity of the charter. The problem is that there is no contractual or any other relationship between the mortgage lender and the bareboat charterer that binds the bareboat charterer to the shipowner mortgage lender. In addition, the lack of any legal relationship between the bareboat charterer and the owner's mortgage lender does not make him liable to the latter if the charterer uses the boat in a way that would reduce the value of the ship, causing a corresponding loss of rights of the insurer.

Adding to the above problem, as mentioned above, are the rules of a different legal order in relation to those of Parallel Registration, which govern the mortgage and the remaining encumbrances on the ship.

The risk to the interests of the mortgage lender is exacerbated by the existence of a condition that appears in many Marine Insurance policies, according to which Marine Insurance automatically terminates in the event of a change of ownership or bareboat chartering the ship. With a condition like the one above, it becomes even more precarious to secure the rights of the mortgage lender, because he will not be able to access the insurance indemnity, either directly as an insured or after its collection by the owner, if the ship in who has registered a mortgage, after the conclusion of a bareboat charter contract and as long as it is under the control of the charterer, its value is destroyed or reduced. This is because the existing 
contract, after the bareboat charter contract, terminates under the aforementioned condition.

But problems can also arise for the owner of the ship. More specifically, he may lose his rights arising from the property relationship that binds him to the ship. This risk may arise in the event that the bareboat charterer's creditors or those making claims against the charterer surrounded by maritime privileges attempt to settle by initiating enforcement proceedings on board. The same risk exists in the event of destruction of the cargo transported during the bareboat chartering of a vessel, in which case the owner of the cargo, to whom the charterer of the naked vessel is responsible, has the option of pledging the ship in order to seek satisfaction.

Finally, the satisfaction of claims against the charterer of bareboat with the imposition of enforcement measures on the ship may be sought by the added charterer who was injured in the chartered ship during the period of the above charter he performed the services for which he was hired by the bareboat charterer.

In the above unfavorable developments for the owner of the ship, there is a possibility of a gap of protection of the owner of the ship due to noninsurance coverage of such a risk. This gap may arise from the following reasons: The first reason is the termination of the insurance contract that concerned the specific ship and was concluded by the owner of the ship under the aforementioned condition, according to which the charter of a bareboat terminates the insurance.

Additional inability to pay insurance compensation to the owner of the ship for which the charterer of the bareboat is responsible for the above reasons may arise in case of non-insurance of this risk by the charterer of the bareboat.

Even the non-conclusion of the appropriate insurance contract by the bareboat charterer can cause financial damage to the owner of the ship by not being able to compensate the owner of the ship for the amount that the latter will be called to pay as a consequence of causing marine pollution due to incorrect maneuvers of the ship by adders of the charterer during the validity of the bareboat charterparty.

Finally, because both the shipowner and the charterer of a bareboat establish an insurance interest of a different nature on their own, in combination with the different liability that may arise for each of them, a lack of insurance agreement may leave them unprotected risks relating to either hull insurance or liability insurance.

Addressing the above issues directly related to Marine Insurance, which could arise during the chartering of a bareboat charter, resulted in the relevant clause of the new version of the standard charter agreement BARECON 2017 undergoing significant changes.

However, the case known as "The Ocean Victory" played a catalytic role mainly for the modification of the above clause on marine insurance and the outcome was that the new version of BARECON was revised. The main amendments are found in its maritime insurance clause and were dictated, inter alia, by the decision of the Supreme Court in the case known as "Ocean Victory".

\section{CONCLUSION}

Parallel Registration is an instrument that can be exercised by the shipping industry in many maritime nations around the world. It has undergone many changes throughout the years of its evolution and it is an acceptable method of the shipping enterprise for the majority of the stakeholders. Among the great supporters of Parallel Registration are the Open Registries and the Flags of Convenience. On the side of the traditional maritime nations the acceptance of Parallel Registration varies depending on the State involved. In some cases the State encourages the maritime interests to seek refuge by registering the vessel in a Parallel Registry, while in other cases States oppose the institution of Parallel Registration.

The positive impact of Parallel Registration can be seen in various aspects of the shipping industry. One such positive outcome has to do with shipping finance. Lending institutions and private funds that wish to invest in the maritime sector tend to trust the legal system of certain Flags that support the interests of the lender when it comes to mortgage. For this reason when the vessel under examination flies the Flag of a non-favorable to the lenders State, then the maritime company has the option to register via Parallel Registration the vessel to a Flag that is most attractive to the investors. Additionally, the maritime company enjoys the freedom to choose the crew of regardless of its nationality. The same level of freedom applies to the ports of call that the vessel can approach.

The States that offer the option of Parallel Registration intend to increase their welfare with various means. For small nations the taxation and fees of the Registry can contribute significantly to the fiscal policy of the State, while in other more developed nations the main target is the creation of a maritime center that attracts maritime activity from around the globe. Furthermore, a fleet that flies the Flag of a State is an asset for national security, since the transportation of the strategic goods is important for the survivability of the population and the continuation of the maritime activities. It is needless to state that the political impact of a State in the maritime industry depends largely on the size of its fleet.

The impact of Parallel Registration to the Marine Insurance extends to a number of issues that affect maritime operations. Especially in the case of bareboat chartering there is the involvement of the owner of the vessel, the bareboat charterer and the mortgage lender. Between these three parties there are certain implications when it comes to Marine Insurance matters. All of these above mentioned parties face a differentiated status due to the fact that the vessel is registered to two Ship Registries. 


\section{REFERENCES}

Ademuni-Odeke. Bareboat Charter (Ship) Registration. Kluwer Law International, 1998.

Ademun-Odeke. "An Examination fo Bareboat Charter Registries and Flag Convenience Registries in International Law." Ocean Development @ International Law 36, no. 4 (2005): 339-362.

Antola, Esko. "The Flag of Convenience System: Freedom of the seas for big capital." Instant Research on Peace and Violence (Tampere Piece Research Institute, University of Tampere) 4, no. 4 (1974): 195-205.

Australian Government - Australian Maritime Safety Authority. 2504 2020. https://www.amsa.gov.au/vesselsoperators/ship-registration/register-vessel-australianinternational-shipping-register (accessed 04 25, 2020).

Bahamas Merchant Shipping Act. "The Bahamas Maritime Authority." Bahamas Maritime. 24042020 https://www.bahamasmaritime.com/wpcontent/uploads/2015/08/Ch-268-Merchant-ShippingAct.pdf (accessed 04 24, 2020).

Bergantino, A.S., and P. O'Sullivan. "Flagging out and International Registries: Main Developments and Policy Issues." International Journal of Transport Economics 26, no. 3 (1999): 447-472.

Bermuda Shipping and Maritime Authority. Bermuda $\begin{array}{llll}\text { Shipping. } & 24 & 04 & 2020\end{array}$ https://www.bermudashipping.bm/registry/demiseregistry/ (accessed 04 24, 2020).

Case Gard Marine and Energy Limited v China National Chartering Co Ltd and another. UKSC 35, (UKSC, 2017)

Clarke, Richard L. "Flags of Convenience." Defense Transportation Journal 45, no. 5 (1989): 68-72.

Coles, Richard M.E., and Edward B. Watt. Ship Registration: Law and Practice. Second Edition. Informa Law, 2009.

Cullinane, Kevin, and Mark Robertshaw. "The influence of qualitative factors in Isle of Man ship registration decisions." Maritime Policy and Management 23, no. 4 (1996): 321-336.

Cyprus Shipping Deputy Ministry. Maritime Cyprus. 2404 2020.

https://www.dms.gov.cy/dms/shipping.nsf/All/37570116 F71F8AC5C2258307002C5F11?OpenDocument\&highlig ht=parallel\%20registry (accessed 04 24, 2020).

Danish Maritime Authority. $2404 \quad 2020$ https://www.dma.dk/Vaekst/Rammevilkaar/Legislation/ Orders/Order\%20on\%20Danish\%20bareboat\%20registra tion.pdf (accessed 04 24, 2020).

Danish Maritime Authority. 24 042020 https://www.dma.dk/SynRegistrering/Skibsregistrering Afgifter/DIS/Bareboat/Sider/default.aspx (accessed 04 24, 2020).

DeSombre, Elizabeth R. "Globalization, Competition and Convergence: Shipping and the Race to the Middle." Global Governance 14, no. 2 (2008): 179-198.

Doganis , R. S., and B. N. Metaxas. The impact of Flags of Convenience. London, 1976.

Farantouris, Nikolaos E. European Integration \& Maritime Transport. Athens: Bruyant, 2003.

Farthing, Bruce, and Mark Brownrigg. Farthing on International Shipping. Third. London, Hong Kong: LLP, 1997.

German Federal Ministry of Transport and Digital Infrastructure. Deutsche Flagge. $2504 \quad 2020$. https://www.deutsche-flagge.de/en/germanflag/changing-to-a-foreign-flag (accessed 04 25, 2020).

Government of Panama. "Panama Ship Registry." 2304 2020.

registry/vessel-

registration/\#ForeignShipRegistryunderBareboatCharter inginPanama (accessed 04 23, 2020).

Harwood, Stephenson. Shipping Finance, Second Edition. London: Euromoney Books, 1996.
Isle of Man Ship Registry. IOM Ship Registry. 24042020. https://www.iomshipregistry.com/registration/shipsdemise/ (accessed 04 24, 2020).

Kiriazidis, Theo, and George Tzanidakis. "Recent aspects of the EU maritime policy." Maritime Policy and Management 22, no. 2 (1995): 179-186.

Koch-Baumgartetn, Sigrid. "Trade Union Regime Formation Under the Conditions of Globalization in the Transport Sector: Attempts at Transnational Trade Union Regulation of Flags-of-Convenience Shipping." International Review of Social History 43, no. 3 (1998): 369-402.

Kremmydas, Vasilis. The Emporium of Peloponnesus during the 18th Century (1715-1792): According to the French Archives (In Greek). Athens, 1972.

Lewis, Peter. "Legal missile holes ships of shame." International Union Rights (International Centre for Trade Union Rights) 10, no. 3 (2003): 21.

Liberian Registry. "LISCR." 23042020. https://www.liscr.com/sites/default/files/online_library/2 $020 \% 20-$

\%20Initial\%20FBCR\%20\%20\%20Rev.01.10.20\%20\%20\%2 8 gm $\% 29 \% 20 \% 28003 \% 29$.pdf (accessed 04 23, 2020).

Mavrommati, Kairou P. Issues of International Law concering the vessels of Flags of Convenience. Athens Thessaloniki: Sakkoulas Publications S.A., 2012.

Mukherjee, Proshanto K. "Flagging options: Legal and Other Considerations." Mariner, Jan/Mar 1993.

Palau International Ship Registry. "The Palau Ship Registry." 2404 2020. https://www.palaureg.com/coreservices/merchant-ship/vessel-registration/bareboatregistration/bareboat-in/ (accessed 04 24, 2020).

Perakis, M. "Current trends in the weakening of the link between the ship's flag and the applicable law." Editions Sakkoulas, 2013.

Petropoulos, Dimos. "PhD Thesis: The role of open registries to modern global economy." University of Piraeus, 2003.

Phang, Sock-Yong, and Rex S. Toh. "Policies to Promote Shipping Registration in Singapore." Journal of Transport Economics and Policy 28, no. 2 (May 1994): 215-219.

Pijaca, M., and B. Bulum. "Insurance of Risks under the Bareboat Charter Contract." Zbornik PFZ (Zbornik PFZ) 67, no. 1 (2017): 85-105.

Republic of the Marshall Islands Maritime and Corporate Registry. International Registries. 23042020. https://www.register-

iri.com/search/?fwp_global_search=parallel\%20registrati on\&fwp_paged $=2$ (accessed 0423,2020 ).

Reuvid, Jonathan. Corporate Investment Opportunities in the New Europe. Kogan Page, 2006.

Shashikumar, N. "Comparative Maritime Policies: A U.S. Dilemm." Transportation Journal (Penn State University Press) 34, no. 1 (1994): 32-38.

Stopford, Martin. Maritime Economics, Third Edition. Routledge, 2009.

Thuong, Le T. "From Flags of Convenience to Captive Ship Registries." Transportation Journal 27, no. 2 (1987): 2234.

Toh, Rex S., and Henry Susilowidjojo. "Flags of Convenience Shipping in the 1980s: The American Perspective." Transportation Journal (Penn State University Press) 26, no. 4 (1987): 34-42.

Toh, Rex S., and Sock Yong Phang. "Quasi-flag of convenience shipping: the wave of the future." Transportation Journal 33, no. 2 (12 1993): 31-39.

UK Public General Acts. 24 042020. http://www.legislation.gov.uk/ukpga/1995/21/part/II/cro ssheading/ships-on-bareboat-charter/enacted (accessed $0424,2020)$.

United Nations. "United Nations Conference on the Law of the Sea (UNCLOS I) - Convention on the High Seas." Treaty Series. Vol. 450. Geneva: United Nations, 29 April 1958. 
United Nations Convention on Conditions for Registration of Ships. United Nations Conference on Trade and Development. $\quad 7 \quad 02 \quad 1986$ http://unctad.org/en/PublicationsLibrary/tdrsconf23_en. pdf (accessed 09 04, 2018).

United Nations Convention on the Law of the Sea (UNCLOS III). United Nations. 1982. http://www.un.org/depts/los/convention_agreements/te xts/unclos/unclos_e.pdf (accessed 04 01, 2018).

Verbeke, A., and W. Winkelmans. "The Strategic search for sustainable country Specific Advantages: Tje case of the European Shipping Industry." International Journal of Transport Economic 17, no. 1 (Feb. 1990): 57-75.

Yannopoulos, G. N. "The Economics of "Flagging Out"." Journal of Transport Economics and Policy 22, no. 2 (1988): 197-207. 